\title{
Nutritional composition and in vitro digestibility of grass and legume winter (cover) crops
}

\author{
A. N. Brown, ${ }^{*}$ G. Ferreira, ${ }^{* 1}$ C. L. Teets, ${ }^{*}$ W. E. Thomason, $\dagger$ and C. D. Teutsch $\ddagger$ \\ *Department of Dairy Science, and \\ †Department of Crop and Soil Environmental Sciences, Virginia Tech, Blacksburg 24061 \\ $\ddagger$ Southern Piedmont Agricultural Research and Extension Center, Virginia Tech, Blackstone 23824
}

\section{ABSTRACT}

In dairy farming systems, growing winter crops for forage is frequently limited to annual grasses grown in monoculture. The objectives of this study were to determine how cropping grasses alone or in mixtures with legumes affects the yield, nutritional composition, and in vitro digestibility of fresh and ensiled winter crops and the yield, nutritional composition, and in vitro digestibility of the subsequent summer crops. Experimental plots were planted with 15 different winter crops at 3 locations in Virginia. At each site, 4 plots of each treatment were planted in a randomized complete block design. The 15 treatments included 5 winter annual grasses [barley (BA), ryegrass (RG), rye (RY), triticale (TR), and wheat (WT)] in monoculture [i.e., no legumes (NO)] or with 1 of 2 winter annual legumes [crimson clover (CC) and hairy vetch (HV)]. After harvesting the winter crops, corn and forage sorghum were planted within the same plots perpendicular to the winter crop plantings. The nutritional composition and the in vitro digestibility of winter and summer crops were determined for fresh and ensiled samples. Growing grasses in mixtures with CC increased forage dry matter $(\mathrm{DM})$ yield $(2.84 \mathrm{Mg} / \mathrm{ha})$, but the yield of mixtures with $\mathrm{HV}(2.47 \mathrm{Mg} / \mathrm{ha})$ was similar to that of grasses grown in monoculture $(2.40 \mathrm{Mg} / \mathrm{ha})$. Growing grasses in mixtures with legumes increased the crude protein concentration of the fresh forage from $13.0 \%$ to $15.5 \%$ for $\mathrm{CC}$ and to $17.3 \%$ for HV. For neutral detergent fiber (NDF) concentrations, the interaction between grasses and legumes was significant for both fresh and ensiled forages. Growing BA, RY, and TR in mixtures with legumes decreased NDF concentrations, whereas growing RG and WT with legumes did not affect the NDF concentrations of either the fresh or the ensiled forages. Growing grasses in mixtures with legumes

Received May 30, 2017.

Accepted November 5, 2017.

${ }^{1}$ Corresponding author: gonf@vt.edu decreased the concentration of sugars of fresh forages relative to grasses grown in monoculture. Primarily, this decrease can be attributed to low concentrations of sugars of mixtures with HV (10.5\%). Growing grasses in mixtures with legumes reduced the fiber digestibility of both winter crops ( $75.7 \%$ to $72.8 \%$ NDF). Growing grasses in mixtures with legumes did not affect estimated DM yield, nutritional composition, or digestibility of the succeeding summer crops. In conclusion, growing grasses in mixtures with legumes as winter forage crops can increase forage estimated DM yields and its nutritional quality in dairy farming sytems.

Key words: cover crop, small grain, legume, silage, digestibility

\section{INTRODUCTION}

Cover crops are planted to increase the health and fertility of soils, to control weeds, and to benefit the environment (SARE, 2007; Myers and Watts, 2015). By covering the soil surface, the vegetative portion of the crops protects the soil from wind and rain erosion. In addition, the roots of the cover crops hold the soil in place, reducing soil erosion from wind and rain. For a corn and soybean rotation, Villamil et al. (2006) observed that soil aggregate stability was increased by 9 to $17 \%$ when cover crops were grown between crops compared with when the ground was left fallow and no cover crops were used during the rotation. Also, growing cover crops decreased bulk density and penetration resistance of the soil and increased total porosity and soil water retention (Villamil et al., 2006).

Different plant species are grown for cover crops. Grass species, such as rye (Secale cereale), annual ryegrass (Lolium multiflorum), or oats (Avena sativa), are the species grown most frequently (Myers and Watts, 2015). The legume species hairy vetch (Vicia villosa) or crimson clover (Trifolium incarnatum) are also used frequently for this purpose (Shipley et al., 1992). Grass species have an extensive and fine fibrous root system, whereas legumes have a tap root system (Stokes et al., 
2009; De Baets et al., 2011; Vannoppen et al., 2015). As fibrous root systems reduce soil erosion more than tap root systems (De Baets et al., 2011), grass species are often recommended for cover crops. Also, as they scavenge more residual soil $\mathrm{N}$ than legume species, growing grass species is advisable to reduce soil nitrate leaching (SARE, 2007; Ketterings et al., 2015). Alternatively, legume species can fix $\mathrm{N}$ from the atmosphere through a symbiotic relationship between legume plants and bacteria in the soil (Hartwig and Ammon, 2002; PlazaBonilla et al., 2015). When left as a cover or mulch, the biomass of the cover crop can provide additional residual $\mathrm{N}$ for the following crop (Shipley et al., 1992). However, in dairy farming systems, where winter crops are harvested and ensiled for feed, this benefit could be marginal or nonexistent. Still, cover crops can contribute to below-ground biomass development (i.e., root growth). For instance, Kuo et al. (1997a) reported that a ryegrass cover crop increased below-ground biomass DM by 120 to $170 \%$ compared with a control treatment without cover crop. Similarly, Kuo et al. (1997b) reported that a hairy vetch cover crop increased belowground $\mathrm{N}$ by $28 \%$ compared with a control treatment without cover crop.

In dairy farming systems, winter forage crops are most frequently annual grasses grown in monoculture (Kaiser et al., 2007; Long et al., 2012). However, based on the potential benefits on soil fertility, the interest in growing grasses in mixtures with legumes has increased over past years. Because grass winter crops can deplete soil N (Ketterings et al., 2015), growing grasses in mixtures with legumes could potentially increase residual soil $\mathrm{N}$ and therefore improve forage yields of the successive summer crops. Miguez and Bollero (2006) reported that rye grown in monoculture reduced the successive corn biomass when no $\mathrm{N}$ was added to the corn, although this detrimental effect was not observed when rye was grown in mixture with hairy vetch.

For this study, we hypothesized that growing grasses in mixtures with legumes, compared with grasses grown in monoculture, would increase forage yield and improve forage quality of winter crops as well as the following summer crop. Therefore, the objectives of this study were to determine how growing grasses alone or in mixtures with legumes affects (1) the estimated yield, nutritional value, and in vitro digestibility of fresh and ensiled winter crops and (2) the estimated yield, nutritional value, and in vitro digestibility of the following summer annual crop (fresh and ensiled).

\section{MATERIALS AND METHODS}

\section{Animal Care and Use}

The Institutional Animal Care and Use Committee of Virginia Tech approved all procedures involving dairy cows for collecting rumen contents (protocol 15-234).

\section{Experimental Sites and Climate Data}

This study was performed from September 2014 to September 2015 at 3 research stations (hereafter referred as sites) located near Blacksburg $\left(37^{\circ} 11^{\prime} 35^{\prime \prime} \mathrm{N}\right.$; $\left.80^{\circ} 34^{\prime} 42^{\prime \prime} \mathrm{W}\right)$, Blackstone $\left(37^{\circ} 05^{\prime} 10^{\prime \prime} \mathrm{N} ; 77^{\circ} 58^{\prime} 34^{\prime \prime} \mathrm{W}\right)$, and Orange $\left(38^{\circ} 13^{\prime} 03^{\prime \prime} \mathrm{N} ; 78^{\circ} 07^{\prime} 38^{\prime \prime} \mathrm{W}\right)$, Virginia. Average monthly temperature and total precipitation data during the experimental period are presented in Table 1. Weather data were collected from weather stations at each site using the National Centers for Environmental Information of the National Oceanic and Atmospheric Administration (NOAA, US Department of Commerce; www.noaa.gov).

Table 1. Average temperature $\left({ }^{\circ} \mathrm{C}\right)$ and total precipitation $(\mathrm{mm})$ during the growing season of 2014-2015

\begin{tabular}{|c|c|c|c|c|c|c|}
\hline \multirow[b]{2}{*}{ Month } & \multicolumn{2}{|c|}{ Blacksburg } & \multicolumn{2}{|c|}{ Blackstone } & \multicolumn{2}{|c|}{ Orange } \\
\hline & Temperature & Precipitation & Temperature & Precipitation & Temperature & Precipitation \\
\hline Sep 2014 & 18.4 & 97 & 20.8 & 107 & 14.3 & 30 \\
\hline Oct 2014 & 12.2 & 104 & 15.2 & 74 & 14.4 & 109 \\
\hline Nov 2014 & 3.18 & 76 & 6.1 & 91 & 5.9 & 69 \\
\hline Dec 2014 & 3.4 & 69 & 5.4 & 91 & 3.8 & 51 \\
\hline Jan 2015 & -0.7 & 33 & 1.6 & 51 & 0.1 & 51 \\
\hline Feb 2015 & -3.4 & 53 & -0.9 & 61 & -2.4 & 36 \\
\hline Mar 2015 & 5.5 & 117 & 6.5 & 89 & 5.4 & 89 \\
\hline Apr 2015 & 11.3 & 132 & 13.6 & 74 & 12.9 & 112 \\
\hline May 2015 & 17.7 & 61 & 20 & 38 & 19.9 & 91 \\
\hline Jun 2015 & 21.8 & 89 & $\mathrm{NA}^{1}$ & NA & 23.1 & 168 \\
\hline Jul 2015 & 22.6 & 109 & 24.6 & 112 & 24.2 & 150 \\
\hline Aug 2015 & 21.4 & 104 & 23.6 & 94 & 23.4 & 15 \\
\hline Sep 2015 & 18.6 & 218 & 21.6 & 112 & 21.2 & 178 \\
\hline
\end{tabular}

${ }^{1} \mathrm{NA}=$ not available. 
Table 2. Planting and harvesting dates for winter and summer crops

\begin{tabular}{|c|c|c|c|c|c|c|}
\hline Item & \multicolumn{2}{|c|}{ Blacksburg } & \multicolumn{2}{|c|}{ Blackstone } & \multicolumn{2}{|c|}{ Orange } \\
\hline Winter crops $^{1}$ & Sep 19, 2014 & Apr 25, 2015 & Oct 8,2014 & Apr 24,2015 & Sep 11, 2014 & Apr 27, 2015 \\
\hline Sorghum & May 8, 2015 & Sep 11, 2015 & May 6,2015 & Sep 1, 2015 & May 12,2015 & Sep 5, 2015 \\
\hline
\end{tabular}

${ }^{1}$ Barley, ryegrass, rye, triticale, and wheat in monoculture or mixed with crimson clover or hairy vetch.

\section{Treatments and Experimental Design}

For the first objective of this study, 5 annual grasses were planted in monoculture (i.e., no legumes; NO) or in mixture with 1 of 2 annual legumes resulting in 15 treatments. Annual grasses included barley (BA; Hordeum vulgare 'Thoroughbred'), ryegrass (RG; 'Marshall'), rye (RY; 'Huron'), triticale (TR; Triticosecale 'Trical 815'), and wheat (WT; Triticum aestivum 'Merl'). Annual legumes included crimson clover (CC; Trifolium incarnatum 'Dixie') and hairy vetch (HV; Vicia villosa 'Purple Bounty'). All seed, except BA and WT, was provided by a regional supplier (King's Agriseeds Inc., Ronks, PA). Barley and WT seed was provided by the Virginia Tech small grain breeding program. Planting dates are presented in Table 2. Planting densities for treatments (Table 3) were selected following guidelines from Brann et al. (2009). Within each site, 4 plots for each of the 15 treatments were planted according to a randomized complete block design (i.e., 60 plots per site) in 9.2-m-long plots consisting of 7 rows separated by $15 \mathrm{~cm}$. For each mixture, grass and legume seeds were combined, mixed, and planted using a no-till experimental drill (Hege 1000, Colwich, KS). Fertilizer was applied before planting at $22 \mathrm{~kg} / \mathrm{ha}$ of N, $56 \mathrm{~kg} / \mathrm{ha}$ of $\mathrm{P}_{2} \mathrm{O}_{5}$, and $45 \mathrm{~kg} / \mathrm{ha}$ of $\mathrm{K}_{2} \mathrm{O}$ in Blacksburg and Orange. Fertilizer was applied before planting at 30 $\mathrm{kg} / \mathrm{ha}$ of $\mathrm{N}$ and $32 \mathrm{~kg} / \mathrm{ha}$ of $\mathrm{K}_{2} \mathrm{O}$ in Blackstone. Winter crops were not fertilized during the spring.

For the second objective of this study, after harvesting the winter crops each plot was split equally in half (i.e., $4.6 \mathrm{~m} \times 1.30 \mathrm{~m}$ ), and each half was planted with either corn (Zea mays Mycogen TMF2L874; Mycogen, Indianapolis, IN) or forage sorghum (Sorghum bicolor
Alta Seeds AF7401; Alta Seeds, Irving, TX) in a direction perpendicular to the winter crop plantings. Both sorghum and corn were planted in $76-\mathrm{cm}$ rows using a no-till planter.

\section{Harvesting Winter Crops}

Due to the complexity of the experiment (i.e., multiple and remote sites and many treatments), a single harvest, regardless of the different winter crops, was conducted at each site (Table 2). Thus, not all winter crops were harvested at the same developmental stage. As a reference, all sites were harvested when BA had inflorescences fully emerged. This stage was chosen so the corn and sorghum could be planted at dates typical for the region (Table 2). Of the remaining winter grasses, RY and TR had three-fourths of inflorescences emerged, whereas RG and WT were harvested at late vegetative stages (i.e., boot stage). Of the legumes, CC was harvested in early- to mid-flowering stage, whereas $\mathrm{HV}$ was harvested in bud to early-flowering stage.

Forage biomass of the whole plot was harvested using a Cibus $\mathrm{F}$ plot forage harvester (Wintersteiger Inc., Salt Lake City, UT) at Blackstone and Orange and a Swift Current Forage Harvester IV (Thompson, 1972) in Blacksburg. After weighing harvested biomass, samples of fresh forages $(\sim 1 \mathrm{~kg})$ were collected in plastic bags, immediately placed in a cooler with dry ice, and transferred to the laboratory for storage at $-20^{\circ} \mathrm{C}$.

\section{Summer Crops}

Within $15 \mathrm{~d}$ after harvesting the winter crops (Table 2 ), corn and sorghum were planted at seeding rates

Table 3. Planting densities (kg/ha) of winter crops

\begin{tabular}{lccc}
\hline Item & Grass (monoculture) & Grass + crimson clover & Grass + hairy vetch \\
\hline Barley & 108 & $54+11$ & $54+11$ \\
Ryegrass & 28 & $14+11$ & $14+11$ \\
Rye & 126 & $63+11$ & $63+11$ \\
Triticale & 126 & $63+11$ & $63+11$ \\
Wheat & 135 & $68+11$ & $68+11$ \\
\hline
\end{tabular}


of 70,000 and 220,000 plants/ha, respectively, using a 6-row John Deere 7200 no-till planter (Deere and Co., Moline, IL) with $76 \mathrm{~cm}$ between rows. Urea was applied at $35 \mathrm{~kg} / \mathrm{ha}$ of $\mathrm{N}$ at planting and $155 \mathrm{~kg} / \mathrm{ha}$ of $\mathrm{N}$ sidedressed at postemergence (i.e., 6 fully expanded leaves) in Blacksburg and Orange. At Blackstone, fertilizer was applied at planting only at a rate of $168 \mathrm{~kg} /$ ha of $\mathrm{N}, 168 \mathrm{~kg} / \mathrm{ha}$ of $\mathrm{P}_{2} \mathrm{O}_{5}$, and $168 \mathrm{~kg} / \mathrm{ha}$ of $\mathrm{K}_{2} \mathrm{O}$. Harvest date (Table 2) was targeted to occur at the one-half milk-line stage of maturity for corn.

At harvest, 5 consecutive plants from 2 center rows (from a total of 6 rows) and at 2 randomly selected spots within each plot (i.e., 10 plants per plot) were cut by hand at $15 \mathrm{~cm}$ above ground level. Whole plants were weighed and chopped with a Stanley $\mathrm{CH} 2$ wood chipper (GXi Outdoor Power LLC, Clayton, NC). After mixing thoroughly within a barrel, samples of fresh forages were collected in plastic bags, immediately placed in a cooler with dry ice, and transferred to the laboratory for storage at $-20^{\circ} \mathrm{C}$. The number of plants per row was counted, and estimated DM yield was determined as plant biomass multiplied by the number of plants per hectare.

\section{Sample Processing}

For the winter crops, samples were thawed and then chopped using a commercial lettuce cutter (Vollrath Redco Lettuce King I; Vollrath Co. LLC, Sheboygan, WI). The length of cut was set at $19 \mathrm{~mm}$. One subsample of the chopped material (hereafter named fresh forage) was dried to a constant weight at $55^{\circ} \mathrm{C}$ in a forced-air oven. The resulting DM concentration was used to determine estimated DM yield of the winter crop. The dried fresh forage was then ground to pass through a 1-mm screen of a cyclone mill (Udy Corp., Fort Collins, CO) before conducting chemical analyses.

A second 400- to 500-g subsample of the chopped material was placed in $620-\mathrm{cm}^{2}$ aluminum pans and wilted using space heaters (Sunbeam Products Inc., Boca Raton, FL) and standing fans (Lasko Products Inc., West Chester, PA). After wilting for approximately $30 \mathrm{~h}$ (until target $30 \%$ of DM), a 400 - to $500-\mathrm{g}$ subsample (hereafter named ensiled forage or silage) was inoculated using Biotal Plus II (Lallemand Animal Nutrition, Milwaukee, WI) following the manufacturer's instructions. The inoculated material was placed into MR-1014 polyethylene embossed pouches (Doug Care Equipment, Springfield, CA) and double sealed anaerobically with a minipack FastVac vacuum sealer (Doug Care Equipment) as described by Der Bedrosian et al. (2012). After $60 \mathrm{~d}$ of fermentation in the dark, mini silos were opened and $\mathrm{pH}$ was determined by blend- ing (Waring Commercial, Torrington, CT) $10 \mathrm{~g}$ of corn silage with $90 \mathrm{~mL}$ of deionized water for $5 \mathrm{~min}$ and immediately measuring $\mathrm{pH}$ (Accumet $\mathrm{AB} 150 \mathrm{pH}$ meter, Fisher Scientific Co., Suwanee, GA). The remaining winter crop silage was dried at $55^{\circ} \mathrm{C}$ in a forced-air drying oven for $48 \mathrm{~h}$ and ground to pass through a 1-mm screen of a cyclone mill.

For corn and sorghum, chopped samples were thawed and a first subsample (hereafter named fresh corn or sorghum) was dried in a forced-air drying oven to a constant weight at $55^{\circ} \mathrm{C}$. The resulting DM concentration was used to estimate DM yield. The dried corn and sorghum were then ground to pass through a 1-mm screen of a cyclone mill for nutritional analyses. A second 400- to 500-g subsample of the thawed sample (hereafter named corn or sorghum silage) was ensiled and then processed as the winter crops except no inoculants were added to enhance fermentation.

\section{Nutritional Composition and Digestibility}

Ash concentration was determined after combusting samples in a furnace for $3 \mathrm{~h}$ at $600^{\circ} \mathrm{C}$ (method 942.05; AOAC International, 2016). Crude protein concentration was calculated as percentage $\mathrm{N} \times 6.25$ after combustion analysis (method 990.03; AOAC International, 2016) using a Vario El Cube CN analyzer (Elementar Americas Inc., Mount Laurel, NJ). Neutral detergent fiber and $\mathrm{ADF}$ concentrations were determined using the Ankom200 Fiber Analyzer (Ankom Technology, Macedon, NY). Sodium sulfite and $\alpha$-amylase (Ankom Technology) were included for NDF analysis. Acid detergent fiber and ADL concentrations were determined sequentially. After determining ADF, the residual fiber was incubated for $3 \mathrm{~h}$ in $72 \%$ sulfuric acid within a 4-L jar that was placed in a DaisyII Incubator (Ankom Technology). Starch concentrations were determined using the acetate buffer method of Hall (2009) with $\alpha$-amylase from Bacillus licheniformis (Ankom Technology) and amyloglucosidase from Aspergillus niger (E-AMGDF; Megazyme International, Wicklow, Ireland). Sugar concentrations were determined as total ethanol/water-soluble carbohydrates as described by Hall et al. (1999).

In vitro DM digestibility, in vitro true DM digestibility (IVTDMD), and in vitro NDF digestibility (IVNDFD) were determined using a DaisyII rotating jar in vitro incubator (Ankom Technology) following the procedures described by Ferreira and Mertens (2005). A composited inoculum was prepared with rumen fluid and rumen solids collected from 3 ruminally cannulated lactating dairy cows (1 Holstein and 2 Jerseys) that were fed a diet containing $43 \%$ corn silage, $6 \%$ triticale 
Table 4. Yield, nutritional composition (DM basis), and digestibility of fresh forage from winter crops

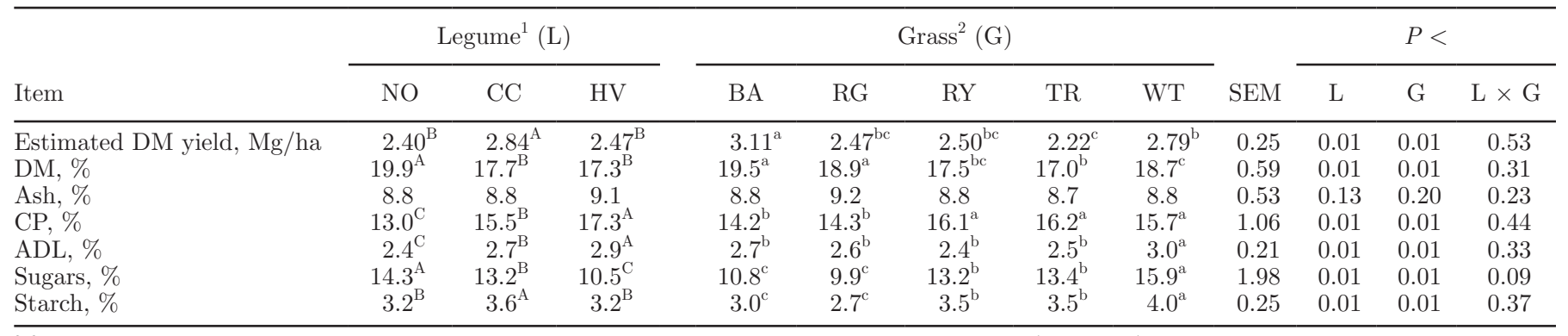

${ }^{a-c}$ Values for grass main effects with different lowercase letters within a row differ statistically $(P<0.05)$.

${ }^{\mathrm{A}-\mathrm{C}}$ Values for legume main effects with different uppercase letters within a row differ statistically $(P<0.05)$.

${ }^{1}$ Main effects of legume: $\mathrm{NO}=$ average of all grasses grown in monoculture; $\mathrm{CC}=$ average of all grasses grown with crimson clover; $\mathrm{HV}=$ average of all grasses grown with hairy vetch.

${ }^{2}$ Main effects of grass: $\mathrm{BA}=$ (barley grown in monoculture + barley grown with crimson clover + barley grown with hairy vetch $) / 3$; RG $=($ ryegrass grown in monoculture + ryegrass grown with crimson clover + ryegrass grown with hairy vetch $) / 3 ; \mathrm{RY}=($ rye grown in monoculture + rye grown with crimson clover + rye grown with hairy vetch $) / 3$; $\mathrm{TR}=($ triticale grown in monoculture + triticale grown with crimson clover + triticale grown with hairy vetch $) / 3 ; \mathrm{WT}=($ wheat grown in monoculture + wheat grown with crimson clover + wheat grown with hairy vetch) $/ 3$.

silage, $4 \%$ alfalfa hay, and $47 \%$ concentrate mix (DM basis).

\section{Statistical Analyses}

All variables were analyzed using the MIXED procedure of SAS (version 9.4; SAS Institute Inc., Cary, $\mathrm{NC}$ ). For the winter crops, data were analyzed as a randomized complete block design using a model that included the effects of site [random, degrees of freedom $(\mathbf{d f})=2$ ], block within site (random, $\mathrm{df}=9$ ), grass (fixed, $\mathrm{df}=4$ ), legume (fixed, $\mathrm{df}=2$ ), the grass $\times$ legume interaction (fixed, $\mathrm{df}=8$ ), and the residual error (random, $\mathrm{df}=154$ ).

For corn and sorghum, data were analyzed as a randomized complete block design in a split plot. The model included the effects of site (random, df $=2$ ), block within site (random, df $=9$ ), grass (fixed, df $=$ 4 ), legume (fixed, $d f=2$ ), the grass $\times$ legume interaction (fixed, $\mathrm{df}=8$ ), the site $\times$ block $\times$ grass $\times$ legume interaction as the whole plot error (random, df $=154$ ), the effect of summer crop (fixed, $\mathrm{df}=1$ ), the interaction of summer crop $\times$ grass (fixed, $\mathrm{df}=4$ ), the interaction of summer crop $\times$ legume (fixed, $\mathrm{df}=2$ ), the interaction of summer crop $\times$ grass $\times$ legume (fixed, $\mathrm{df}=8$ ), and the residual error (random, df $=165$ ). Significant differences and tendencies to differ were declared at $P$ $<0.05$ and $P<0.10$, respectively.

\section{RESULTS AND DISCUSSION}

\section{Winter Crop Yield, Quality, and Digestibility}

One objective of this study was to determine the effect of growing grasses in mixtures with legumes on for- age yield, nutritional quality, and digestibility. Growing grasses in mixtures with legumes tended to increase forage estimated DM yields (Table 4). This increase was attributed to the yield of mixtures with $\mathrm{CC}(2.84 \mathrm{Mg}$ / ha) only, as yields of mixtures with $\mathrm{HV}(2.47 \mathrm{Mg} / \mathrm{ha})$ were similar to those of grasses grown in monoculture $(2.40 \mathrm{Mg} / \mathrm{ha})$. Among grasses, BA had the greatest estimated DM yields (3.11 Mg/ha) and TR, RG, and RY had the lowest (mean $=2.40 \mathrm{Mg} / \mathrm{ha}$ ) estimated DM yields. Carr et al. (2004) reported respective DM yields of 2.91 and $3.84 \mathrm{Mg} / \mathrm{ha}$ for barley and oats grown in monoculture. However, DM yields increased to 3.53 and $4.56 \mathrm{Mg} / \mathrm{ha}$, respectively, when barley and oats were grown in mixtures with peas. Similarly, growing oats in mixtures with vetch increased forage yield 10 to $35 \%$ relative to oats grown in monoculture (Kaiser et al., 2007). However, depending on harvesting time, the increase of forage yield ranged from 0 to $18 \%$ when ryegrass was grown in mixtures with vetch relative to ryegrass grown in monoculture (Kaiser et al., 2007).

Forage DM yields were lower than those observed for triticale and wheat (4.6 and $3.7 \mathrm{Mg} / \mathrm{ha}$, respectively) in Virginia during 2015 (Thomason et al., 2015). There are 2 major reasons for these differences. First, we harvested the winter crops in early spring (Lawson et al., 2015) as we prioritized planting the following summer crop at early dates to maximize forage yield. Second, under the assumption that growing grasses with legumes would provide additional $\mathrm{N}$, we fertilized with $\mathrm{N}$ only at planting (fall 2014) and not during the growing season (spring 2015).

It is worth mentioning that the low fertilization rates and the single and early dates for harvesting different winter crops were intentional. Under the concept that legumes add fertility to the soil, we challenged 
the system for the legumes to reflect their potential to increase residual fertility for the following summer crop. In regards to harvesting, early and late harvesting dates have positive and negative effects. Delaying harvesting would likely increase forage yields of the winter crop, although it may deplete moisture and fertility for the following summer crop. As a secondary effect, a delayed planting date of the summer crop can also expose silking time to periods of heat stress, which may be detrimental to forage yield and quality (Ferreira et al., 2015). In contrast, harvesting winter crops early may improve the growing conditions for the following summer crop, albeit at the expense of DM yield of the preceding winter crop. Although somewhat unlikely, dairy farmers may elect to kill the winter crop rather than harvesting it as silage. Finally, the single harvest date for all winter crops was decided based on a single (optimum) planting date for the summer crops; different planting dates would have confounded the growth responses of the summer annual forage.

Growing grasses in mixtures with legumes increased the $\mathrm{CP}$ concentration of the fresh forage (Table 4) from $13.0 \%$ to $15.5 \%$ for $\mathrm{CC}$ and to $17.3 \%$ for HV. After ensiling, the $\mathrm{CP}$ of silages containing legumes also was greater than silages from grasses only (Table 5). As for the fresh forages, the concentration of $\mathrm{CP}$ in silages was also greater for $\mathrm{HV}$ than for CC (18.3 and 16.6\%, respectively). Among grasses, the concentration of $\mathrm{CP}$ in fresh forage (Table 4) was lower for BA and RG $(14.3 \%)$ than for the other grasses (16.0\%). Generally, similar trends were observed for ensiled forages (Table $5)$.

For NDF concentration, the interaction between grasses and legumes was significant for both fresh $(P<$
0.01; Figure 1) and ensiled (data not shown) forages. Growing BA, RY, and TR in mixtures with legumes decreased NDF concentrations, whereas growing RG and WT with legumes did not change NDF concentrations of either the fresh or the ensiled forages. Grasses usually contain greater fiber concentrations than legumes (Fulkerson et al., 2007; Kammes and Allen, 2012; Ergon et al., 2016). Therefore, growing grasses in mixtures with legumes containing lower fiber concentrations likely reduces the NDF concentrations in the harvested forage. Similar to our study, Carr et al. (2004) reported lower NDF concentrations of fresh forage when barley and oats were intercropped with peas compared with barley and oats grown in monoculture $(58.4 \%$ vs. $50.8 \%$ for barley and $61.8 \%$ vs. $55.2 \%$ for oats). The lower NDF concentrations in our grass-legume mixtures indicate that adding legumes to grasses may increase the energy concentration of winter crop forages (Carr et al., 2004).

Among grasses, NDF concentrations of fresh forages were lowest for RG (43.1\%) and greatest for BA (57.4\%; Figure 1). We relate the greatest estimated DM yield and NDF concentration observed for BA to the more advanced growth stage (i.e., inflorescence fully emerged) relative to the growth stage of other grasses. The lower concentrations of NDF in RG and WT explain the interaction observed between grasses and legumes. Even though we did not measure it in pure legumes, the concentrations of NDF for these 2 grasses would be proximate to the concentration of NDF of the legumes (Figure 1).

Growing grasses in mixtures with legumes decreased the concentration of sugars within fresh forages relative to grases grown in monoculture (Table 4). Lower con-

Table 5. Postfermentation pH, nutritional composition (DM basis), and digestibility of ensiled forage from winter crops

\begin{tabular}{|c|c|c|c|c|c|c|c|c|c|c|c|c|}
\hline \multirow[b]{2}{*}{ Item } & \multicolumn{3}{|c|}{ Legume $^{1}(\mathrm{~L})$} & \multicolumn{5}{|c|}{$\operatorname{Grass}^{2}(\mathrm{G})$} & \multirow[b]{2}{*}{ SEM } & \multicolumn{3}{|c|}{$P<$} \\
\hline & NO & $\mathrm{CC}$ & $\mathrm{HV}$ & BA & $\mathrm{RG}$ & $\mathrm{RY}$ & TR & WT & & $\mathrm{L}$ & G & $\mathrm{L} \times \mathrm{G}$ \\
\hline Ash, $\%$ & $9.0^{\mathrm{B}}$ & $10.2^{\mathrm{A}}$ & $10.4^{\mathrm{A}}$ & $9.3^{\mathrm{b}}$ & $10.6^{\mathrm{a}}$ & $9.5^{\mathrm{b}}$ & $10.3^{\mathrm{a}}$ & $9.5^{\mathrm{b}}$ & 0.95 & 0.01 & 0.01 & 0.91 \\
\hline CP, \% & $14.2^{\mathrm{C}}$ & $16.6^{\mathrm{B}}$ & $18.3^{\mathrm{A}}$ & $15.1^{\mathrm{d}}$ & $15.8^{\mathrm{cd}}$ & $16.5^{\mathrm{bc}}$ & $17.3^{\mathrm{a}}$ & $17.0^{\mathrm{ab}}$ & 0.80 & 0.01 & 0.01 & 0.32 \\
\hline $\mathrm{ADF}, \%$ & $29.9^{\mathrm{B}}$ & $29.3^{\mathrm{B}}$ & $31.5^{\mathrm{A}}$ & $32.6^{\mathrm{a}}$ & $28.7^{\mathrm{b}}$ & $31.9^{\mathrm{a}}$ & $29.2^{\mathrm{b}}$ & $28.9^{\mathrm{b}}$ & 1.45 & 0.01 & 0.01 & 0.27 \\
\hline IVNDFD, ${ }^{3} \%$ of NDF & $74.4^{\mathrm{A}}$ & $71.5^{\mathrm{B}}$ & $71.1^{\mathrm{B}}$ & $69.0^{\mathrm{c}}$ & $74.8^{\mathrm{a}}$ & $71.4^{\mathrm{b}}$ & $73.3^{\mathrm{ab}}$ & $73.2^{\mathrm{ab}}$ & 2.02 & 0.01 & 0.01 & 0.73 \\
\hline
\end{tabular}

${ }^{\mathrm{a}-\mathrm{d}}$ Values for grass main effects with different lowercase letters within a row differ $(P<0.05)$.

${ }^{\mathrm{A}-\mathrm{C}}$ Values for legume main effects with different uppercase letters within a row differ $(P<0.05)$.

${ }^{1}$ Main effects of legume: $\mathrm{NO}=$ average of all grasses grown in monoculture; $\mathrm{CC}=$ average of all grasses grown with crimson clover; $\mathrm{HV}=$ average of all grasses grown with hairy vetch.

${ }^{2}$ Main effects of grass: BA $=$ (barley grown in monoculture + barley grown with crimson clover + barley grown with hairy vetch $) / 3$; RG $=($ ryegrass grown in monoculture + ryegrass grown with crimson clover + ryegrass grown with hairy vetch $) / 3 ; \mathrm{RY}=($ rye grown in monoculture + rye grown with crimson clover + rye grown with hairy vetch $) / 3$; TR $=($ triticale grown in monoculture + triticale grown with crimson clover + triticale grown with hairy vetch $) / 3 ; \mathrm{WT}=($ wheat grown in monoculture + wheat grown with crimson clover + wheat grown with hairy vetch) $/ 3$. ${ }^{3}$ IVNDFD $=$ in vitro NDF digestibility. 
centrations of sugars in legumes relative to grasses were reported previously (Kaiser et al., 2007; Ergon et al., 2016). The lower concentration of sugars was counterbalanced by greater protein and, to a lesser extent, by changes in the concentration of NDF. Because sugars are the substrate for lactic acid bacteria during the ensiling process, sugar concentrations decreased substantially for all silages after the ensiling process (Table 5). Sugar concentration of ensiled samples followed a similar trend observed in fresh samples, as including $\mathrm{HV}$ in the winter crop mixture reduced sugar concentrations in the silage. However, the magnitude of this difference has minimal nutritional implications.

Among grasses, WT had the greatest (15.9\%) and BA and RG had the lowest concentrations of sugars in fresh forage (10.4 and 9.9\%, respectively; Table 4). Despite this, the concentration of sugars was similar in the ensiled forage (Table 5). As sugars are the substrates for microbes during the ensiling process, the concentrations of sugars in fresh forage were negatively correlated with silage $\mathrm{pH}(-0.41<\mathrm{r}<-0.23$; data not shown).

The silage $\mathrm{pH}$ of grasses grown in mixtures with $\mathrm{HV}(\mathrm{pH}=4.42)$ was greater than the silage $\mathrm{pH}$ of the grasses grown in monoculture $(\mathrm{pH}=4.14$; Table 5$)$. The silage $\mathrm{pH}$ of grasses grown in mixtures with $\mathrm{CC}(\mathrm{pH}=$ 4.19) was similar to the silage $\mathrm{pH}$ of the grasses grown in monoculture. A lower $\mathrm{pH}$ usually indicates a more adequate ensiling process. In our study, differences in
$\mathrm{pH}$ were linked to differences in sugar concentrations of the fresh forage. However, as sugar concentrations were adequate to ensure appropriate silage fermentation, changes in $\mathrm{pH}$ may also relate to differences in buffering capacities of the forages or a combination of buffering capacity and concentration of sugars (Kaiser et al., 2007; Coblentz and Muck, 2012; Coblentz et al., 2016). Overall, ensiling grasses in mixtures with HV may be more challenging to lower silage $\mathrm{pH}$ than ensiling monocultures or mixtures of grasses with CC.

For both fresh $(P<0.01)$ and ensiled (data not shown) forages, an interaction existed between grass species and the addition of legumes for IVTDMD (Figure 2). For the fresh forage, the addition of legumes to RG and WT reduced the IVTDMD. However, with the addition of legumes to BA, RY, and TR, IVTDMD remained the same. The ratio of lignin to fiber is greater for legumes than for grasses (Kuoppala et al., 2009). For RG and WT, the lower IVTDMD would be related to a greater lignin:fiber ratio and, therefore, lower digestibility of NDF, as adding legumes did not affect the concentration of NDF.

Similar to IVTDMD, the interaction for IVNDFD between grass species and the addition of legumes was significant for fresh forages $(P<0.03$; Figure 3$)$. The addition of legumes to RG, TR, and WT lowered the IVNDFD of the fresh forages. However, with the addition of legumes to BA and RY, IVNDFD remained the same.

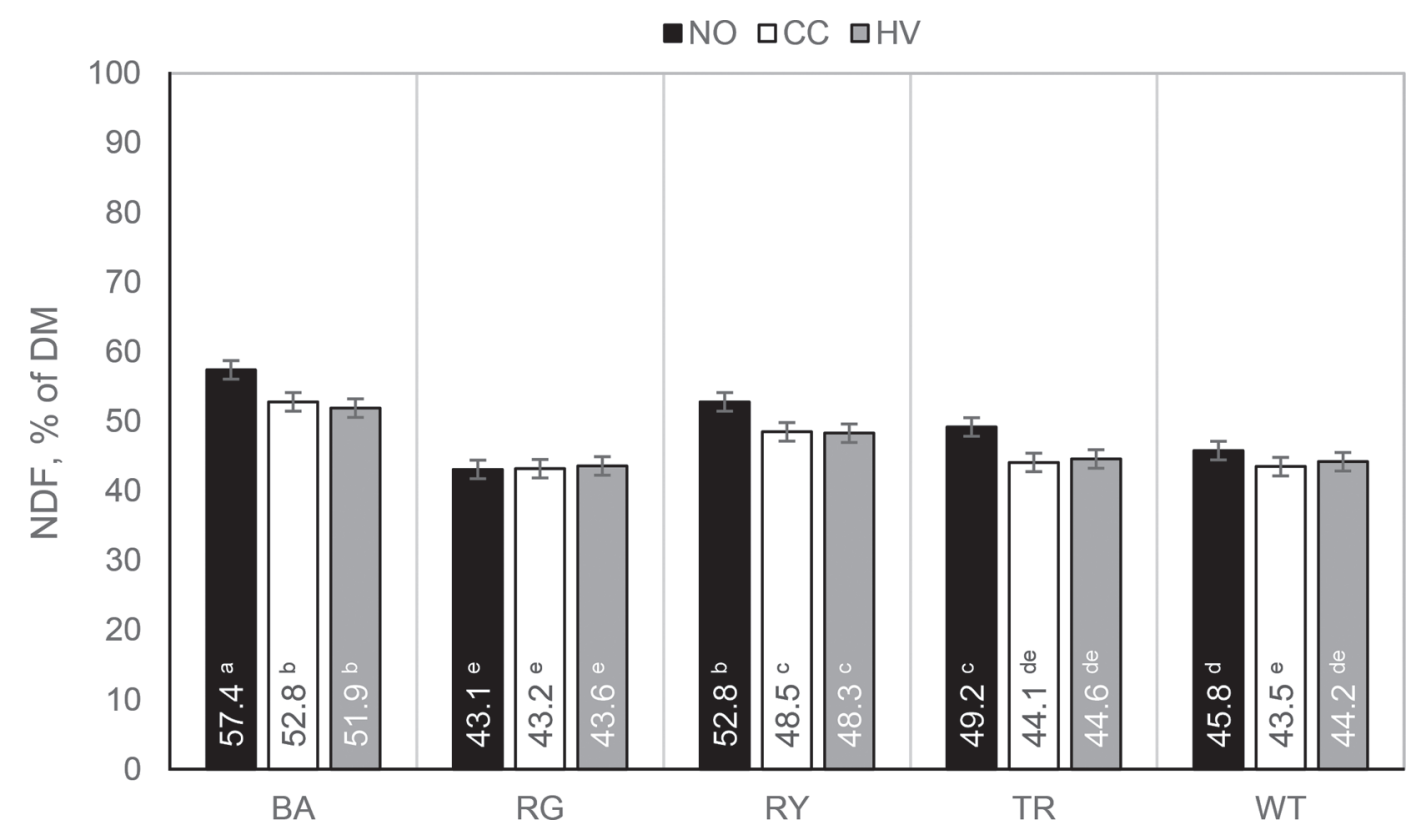

Figure 1. Concentration of NDF in fresh forages (DM basis) harvested from different winter crops. Five grasses (barley [BA], ryegrass [RG], rye $[\mathrm{RY}]$, triticale $[\mathrm{TR}]$, and wheat $[\mathrm{WT}]$ ) were grown in monoculture or in mixtures with 2 legumes (crimson clover $[\mathrm{CC}]$ and hairy vetch $[\mathrm{HV}]$ ). $\mathrm{NO}=$ no legumes. Treatment means with different letters $(\mathrm{a}-\mathrm{e})$ differ $(P<0.05)$. Error bars are SEM $=1.33$. 




Figure 2. In vitro true DM digestibility (IVTDMD) in fresh forages (DM basis) harvested from different winter crops. Five grasses (barley $[\mathrm{BA}]$, ryegrass $[\mathrm{RG}]$, rye $[\mathrm{RY}]$, triticale $[\mathrm{TR}]$, and wheat $[\mathrm{WT}]$ ) were grown in monoculture or in mixtures with 2 legumes (crimson clover $[\mathrm{CC}]$ and hairy vetch $[\mathrm{HV}])$. NO $=$ no legumes. Treatment means with different letters $(\mathrm{a}-\mathrm{d})$ differ $(P<0.05)$. Error bars are SEM $=1.84$.

Fiber digestibility of legumes is usually lower than fiber digestibility of grasses (Voelker-Linton and Allen, 2008). Legumes have more lignin than grasses on a DM basis (Kuoppala et al., 2009). The lignin of legumes is all concentrated in the xylem, whereas the lignin of grasses is spread out evenly among all tissues except the phloem (Wilson and Kennedy, 1996). The xylem of legumes is almost completely indigestible, but the

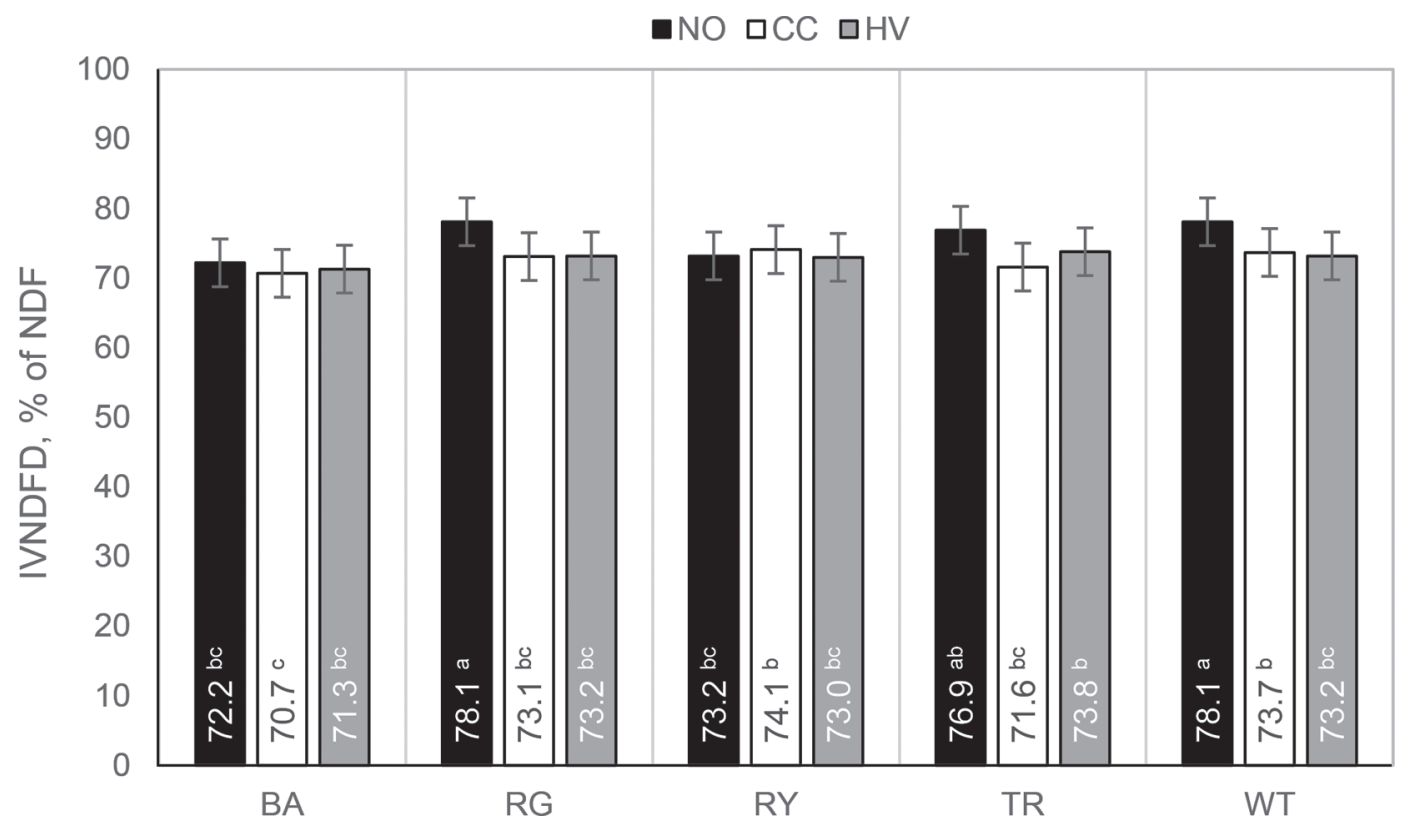

Figure 3. In vitro NDF digestibility (IVNDFD) in fresh forages (\% NDF) harvested from different winter crops. Five grasses (barley [BA], ryegrass $[\mathrm{RG}]$, rye $[\mathrm{RY}]$, triticale $[\mathrm{TR}]$, and wheat $[\mathrm{WT}]$ ) were grown in monoculture or in mixtures with 2 legumes (crimson clover [CC] and hairy vetch $[\mathrm{HV}]) . \mathrm{NO}=$ no legumes. Treatment means with different letters $(\mathrm{a}-\mathrm{c})$ differ $(P<0.05)$. Error bars are SEM $=3.43$. 
Table 6. Yield, nutritional composition (DM basis), and fiber digestibility of fresh summer crops and postfermentation pH, nutritional composition, and fiber digestibility of fresh and ensiled summer crops as affected by preceding winter crops

\begin{tabular}{|c|c|c|c|c|c|c|c|c|c|c|c|c|c|c|c|}
\hline \multirow[b]{2}{*}{ Item } & \multicolumn{3}{|c|}{ Legume $^{1}(\mathrm{~L})$} & \multicolumn{5}{|c|}{$\operatorname{Grass}^{2}(\mathrm{G})$} & \multicolumn{2}{|c|}{$\mathrm{SC}^{3}$} & \multirow[b]{2}{*}{ SEM } & \multicolumn{4}{|c|}{$P<$} \\
\hline & NO & $\mathrm{CC}$ & HV & $\mathrm{BA}$ & RG & RY & $\mathrm{TR}$ & $\mathrm{WT}$ & $\mathrm{C}$ & S & & $\mathrm{L}$ & G & $\mathrm{L} \times \mathrm{G}$ & $\mathrm{SC}$ \\
\hline Estimated DM yield, $\mathrm{Mg} / \mathrm{ha}$ & 15.6 & 15.0 & 14.6 & $16.7^{\mathrm{a}}$ & $14.0^{\mathrm{b}}$ & $15.3^{\mathrm{ab}}$ & $15.5^{\mathrm{a}}$ & $14.0^{\mathrm{b}}$ & 14.9 & 15.3 & 1.00 & 0.28 & 0.01 & 0.21 & 0.47 \\
\hline $\mathrm{DM}, \%$ & 27.8 & 27.2 & 27.5 & 27.8 & 26.7 & 28.0 & 27.5 & 27.4 & 28.5 & 26.5 & 1.62 & 0.10 & 0.01 & 0.03 & 0.01 \\
\hline Ash. \% & 4.3 & 4.3 & 4.3 & 4.4 & 4.4 & 4.2 & 4.3 & 4.3 & 3.5 & 5.1 & 0.12 & 0.59 & 0.09 & 0.15 & 0.01 \\
\hline $\mathrm{CP}, \%$ & 10.5 & 10.7 & 10.5 & 10.6 & 10.6 & 10.3 & 10.6 & 10.6 & 10.0 & 11.1 & 0.37 & 0.26 & 0.41 & 0.46 & 0.01 \\
\hline \multicolumn{16}{|l|}{ Silage } \\
\hline $\mathrm{pH}$ & 3.72 & 3.70 & 3.72 & 3.72 & 3.70 & 3.71 & 3.71 & 3.72 & 3.65 & 3.78 & 0.02 & 0.46 & 0.82 & 0.80 & 0.01 \\
\hline DM, \% & 28.0 & 27.8 & 27.8 & 28.1 & 27.2 & 28.3 & 28.1 & 27.7 & 28.7 & 27.0 & 1.89 & 0.78 & 0.05 & 0.06 & 0.01 \\
\hline Ash, $\%$ & 4.5 & 4.5 & 4.5 & 4.5 & 4.5 & 4.4 & 4.5 & 4.5 & 3.5 & 5.4 & 0.07 & 0.93 & 0.71 & 0.04 & 0.01 \\
\hline $\mathrm{CP}, \%$ & 10.4 & 10.5 & 10.4 & 10.4 & 10.3 & 10.4 & 10.5 & 10.5 & 10.2 & 10.7 & 0.45 & 0.87 & 0.73 & 0.91 & 0.01 \\
\hline $\mathrm{NDF}, \%$ & 44.4 & 45.8 & 45.7 & 45.2 & 46.1 & 44.7 & 44.8 & 45.7 & 41.3 & 49.3 & 1.31 & 0.11 & 0.49 & 0.11 & 0.01 \\
\hline IVNDFD, $\%$ of NDF & 44.2 & 44.2 & 44.3 & 44.3 & 44.9 & 43.9 & 43.9 & 44.2 & 42.6 & 45.9 & 0.74 & 0.97 & 0.43 & 0.16 & 0.01 \\
\hline
\end{tabular}

${ }_{\mathrm{a}, \mathrm{b}}$ Values for grasses with different superscripts within a row differ $(P<0.05)$.

${ }^{1}$ Main effects of legume: $\mathrm{NO}=$ average of all grasses grown in monoculture; $\mathrm{CC}=$ average of all grasses grown with crimson clover; $\mathrm{HV}=$ average of all grasses grown with hairy vetch.

${ }^{2}$ Main effects of grass: BA $=($ barley grown in monoculture + barley grown with crimson clover + barley grown with hairy vetch $) / 3 ;$ RG $=($ ryegrass grown in monoculture + ryegrass grown with crimson clover + ryegrass grown with hairy vetch $) / 3 ; \mathrm{RY}=($ rye grown in monoculture + rye grown with crimson clover + rye grown with hairy vetch) $/ 3 ; \mathrm{TR}=($ triticale grown in monoculture + triticale grown with crimson clover + triticale grown with hairy vetch) $/ 3 ; \mathrm{WT}=($ wheat grown in monoculture + wheat grown with crimson clover + wheat grown with hairy vetch) $/ 3$.

${ }^{3}$ Main effects of summer crop (SC): corn (C) vs. sorghum (S).

${ }^{4}$ IVNDFD $=$ in vitro NDF digestibility.

remaining tissues are very digestible; therefore, the passage rate of legumes is faster than that of grasses because the lower concentration of indigestible fiber inhibits the passage rate of grasses (Kuoppala et al., 2009). The greater concentration of lignin and faster passage rate decreases the fiber digestibility of legumes. However, legumes usually have a lower fiber concentration and higher NFC concentration compared with grasses. Therefore, even though in some cases IVNDFD was reduced with the addition of legumes (Figure 3), the concentration of highly digestible nonfibrous components was greater in the mixtures than in the monocultures (Figure 1), thereby maintaining the nutritive value of the silage.

\section{Summer Crops Yield, Quality, and Digestibility}

The second major objective of this study was to determine the effect of growing different winter crops on forage yield, nutritional quality, and digestibility of the following summer crop. Relative to growing grasses in monoculture, growing winter-annual grasses in mixtures with legumes did not change estimated DM yields of corn or sorghum (Table 6), indicating no measurable benefits for growing grasses in mixtures with legumes. Gabriel and Quemada (2011) reported that when barley or hairy vetch were used as a cover crop for corn, corn yields were similar to a bare fallow control; however, corn took up more $\mathrm{N}$ following vetch cover compared with the bare fallow control. In our study, the winter crops were harvested for silage and the above-ground biomass was not left as cover for the following summer crop; therefore, any advantage of adding legumes to the grasses may have been lost due to the small amount of residue remaining. Alternatively, cover crops can promote below-ground biomass development (Kuo et al., 1997a, b).

In addition to the similar estimated DM yields, in our study the nutritional composition and digestibility of the fresh and ensiled summer crops remained the same with the addition of legumes (Table 6). This was the case for both corn and sorghum crops.

Plots containing RG and WT reduced yield of both corn and sorghum (14.0 Mg/ha) compared with other grasses (16.7 and $15.5 \mathrm{Mg} / \mathrm{ha}$ for $\mathrm{BA}$ and $\mathrm{TR}$, respectively; Table 6). Despite herbicide application after harvesting the winter crops, we observed a regrowth of RG after emergence of summer crops, which resulted in high weed pressure during early growth, therefore reducing DM yields. Although ryegrass can be an excellent cover crop, its resilience to herbicide applications can make ryegrass termination extremely difficult (Legleiter et al., 2015).

There were differences in nutrient composition but not yield between the 2 summer crops (corn vs. sorghum). As the interactions of summer crop $\times$ grasses, 
summer crop $\times$ legumes, and summer crop $\times$ grasses $\times$ legumes were not significant (data not shown), no effects of winter crops on yield, nutritional composition, and digestibility of the fresh and ensiled forages were observed for the following summer crops (Table 6).

\section{CONCLUSIONS}

In this 1-yr study within the Mid-Atlantic region, growing grasses in mixtures with $\mathrm{CC}$ as winter crops for forage increased forage estimated DM yields in dairy farming sytems, although this was not the case for HV. Also, growing grasses with legumes increased the concentration of $\mathrm{CP}$, whereas it decreased the concentrations of NDF and sugars. As tissues from legumes have more lignified cell walls, there can be a decrease in fiber digestibility when grasses are grown with mixtures. Despite the lower fiber digestibility, the energy can be maintained by the lower fiber concentration when growing grasses in mixtures with legumes. Finally, under the conditions of this study, the inclusion of legume species in the winter crop for forages did not affect the yield, nutritional composition, or digestibility of the succeeding corn or sorghum.

\section{ACKNOWLEDGMENTS}

We thank Steve Gulick and Elizabeth Rucker (Department of Crop and Soil Environmental Sciences) for their assistance in preparing the experimental plots. We also thank Yang Yang (Department of Dairy Science) for assistance with harvesting plots. Finally, we thank King's Agriseeds (Ronks, PA) for donating the seeds for winter crops (i.e., ryegrass, rye, triticale, crimson clover, and hairy vetch), Advanta Seeds (Irving, TX) for donating the seeds for forage sorghum, and Lallemand Inc. (Milwaukee, WI) for donating the silage inoculant. This project was funded mainly by the USDA Natural Resources Conservation Virginia Conservation Innovation Grant program and partially by USDA National Institute of Food and Agriculture Hatch Project VA-160025 and USDA National Institute of Food and Agriculture Multistate Project VA-136291 (NC-2042, Management Systems to Improve the Economic and Environmental Sustainability of Dairy Enterprises).

\section{REFERENCES}

AOAC International. 2016. Official Methods of Analysis of AOAC International. 20th ed. AOAC International, Rockville, MD.

Brann, D. E., D. L. Holshouser, and G. L. Mullins. 2009. Agronomy Handbook. Publication 424-100. Virginia Cooperative Extension, Blacksburg.
Carr, P. M., R. D. Horsley, and W. W. Poland. 2004. Barley, oat and cereal-pea mixtures as dryland forages in the northern great plains. Agron. J. 96:677-684.

Coblentz, W. K., K. P. Coffey, and E. A. Chow. 2016. Storage characteristics, nutritive value, and fermentation characteristics of alfalfa packaged in large-round bales and wrapped in stretch film after extended time delays. J. Dairy Sci. 99:3497-3511.

Coblentz, W. K., and R. E. Muck. 2012. Effects of natural and simulated rainfall on indicators of ensilability and nutritive value for wilting alfalfa forages sampled before preservation as silage. J. Dairy Sci. 95:6635-6653.

De Baets, S., J. Poesen, J. Meersmans, and L. Serlet. 2011. Cover crops and their erosion-reducing effects during concentrated flow erosion. Catena 85:237-244.

Der Bedrosian, M. C., K. E. Nestor, and L. Kung. 2012. The effects of hybrid, maturity, and length of storage on the composition and nutritive value of corn silage. J. Dairy Sci. 95:5115-5126.

Ergon, A., L. Kirwan, G. Fystro, M. A. Bleken, R. P. Collins, and O A. Rognli. 2016. Species interactions in a grassland mixture under low nitrogen fertilization and two cutting frequencies. II. Nutritional quality. Grass Forage Sci. 72:333-342.

Ferreira, G., H. Behl, E. Hokanson, W. E. Thomason, and C. D Teutsch. 2015. The interaction of drought stress and heat stress as determinant of dry matter yield and nutritional composition of maize (Zea mays L.) whole-plant for silage. Maydica 60:M6.

Ferreira, G., and D. R. Mertens. 2005. Chemical and physical characteristics of corn silages and their effects on in vitro disappearance. J. Dairy Sci. 88:4414-4425.

Fulkerson, W. J., J. S. Neal, C. F. Clark, A. Horadagoda, K. S. Nandra, and I. Barchia. 2007. Nutritive value of forage species grown in the warm temperate climate of Australia for dairy cows: Grasses and legumes. Livest. Sci. 107:253-264.

Gabriel, J. L., and M. Quemada. 2011. Replacing bare fallow with cover crops in a maize cropping system: Yield, $\mathrm{N}$ uptake and fertiliser fate. Eur. J. Agron. 34:133-143.

Hall, M. B. 2009. Determination of starch, including maltooligosaccharides, in animal feeds: Comparison of methods and a method recommended for AOAC collaborative study. J. AOAC Int. 92:42-49.

Hall, M. B., W. H. Hoover, J. P. Jennings, and T. K. M. Webster. 1999. A method for partitioning neutral detergent-soluble carbohydrates. J. Sci. Food Agric. 79:2079-2086.

Hartwig, N. L., and H. U. Ammon. 2002. Cover crops and living mulches. Weed Sci. 50:688-699.

Kaiser, A. G., B. S. Dear, and S. G. Morris. 2007. An evaluation of the yield and quality of oat-legume and ryegrass-legume mixtures and legume monocultures harvested at three stages of growth for silage. Aust. J. Exp. Agric. 47:25-38.

Kammes, K. L., and M. S. Allen. 2012. Rates of particle size reduction and passage are faster for legume compared with cool-season grass, resulting in lower rumen fill and less effective fiber. J. Dairy Sci. 95:3288-3297.

Ketterings, Q. M., S. N. Swink, S. W. Duiker, K. J. Czymmek, D. B. Beegle, and W. J. Cox. 2015. Integrating cover crops for nitrogen management in corn systems on northeastern U.S. dairies. Agron. J. 107:1365-1376.

Kuo, S., U. M. Sainju, and E. J. Jellum. 1997a. Winter cover crop effects on soil organic carbon and carbohydrate in soil. Soil Sci. Soc. Am. J. 61:145-157.

Kuo, S., U. M. Sainju, and E. J. Jellum. 1997b. Winter cover cropping influence on nitrogen soil. Soil Sci. Soc. Am. J. 61:1392-1399.

Kuoppala, K., S. Ahvenjärvi, M. Rinne, and A. Vanhatalo. 2009. Effects of feeding grass or red clover silage cut at two maturity stages in dairy cows. 2. Dry matter intake and cell wall digestion kinetics. J. Dairy Sci. 92:5634-5644.

Lawson, A., C. Cogger, A. Bary, and A.-M. Fortuna. 2015. Influence of seeding ratio, planting date, and termination date on rye-hairy vetch cover crop mixture performance under organic management. PLoS One 10:e0129597.

Legleiter, T., W. Johnson, and B. Young. 2015. Terminating cover crops: Succesful annual ryegrass termination with herbicides. Pub- 
lication WS-52-W. Purdue University Cooperative Extension Service, West Lafayette, IN.

Long, E., Q. M. Ketterings, and K. J. Czymmek. 2012. Survey of cover crop use on New York dairy farms. Accessed May 22, 2017. http:// nmsp.cals.cornell.edu/Announcements/CoverCropSurvey2012.pdf.

Miguez, F. E., and G. A. Bollero. 2006. Winter cover crops in Illinois: Evaluation of ecophysiological characteristics of corn. Crop Sci. 46:1536-1545.

Myers, R., and C. Watts. 2015. Progress and perspectives with cover crops: Interpreting three years of farmer surveys on cover crops. J. Soil Water Conserv. 70:125A-129A.

Plaza-Bonilla, D., J.-M. Nolot, D. Raffaillac, and E. Justes. 2015. Cover crops mitigate nitrate leaching in cropping systems including grain legumes: Field evidence and model simulations. Agric. Ecosyst. Environ. 212:1-12.

SARE (Sustainable Agriculture Research and Education). 2007. Managing Cover Crops Profitably. 3rd ed. SARE Handbook Series Book 9. SARE, College Park, MD.

Shipley, P. R., J. J. Meisinger, and A. M. Decker. 1992. Conserving residual corn fertilizer nitrogen with winter cover crops. Agron. J. 84:869-876.
Stokes, A., C. Atger, A. G. Bengough, T. Fourcaud, and R. C. Sidle. 2009. Desirable plant root traits for protecting natural and engineered slopes against landslides. Plant Soil 324:1-30.

Thomason, W. E., S. Gulick, and E. Hokanson. 2015. Small Grain Forage Variety Testing, 2015. CSES-127NP. Virginia Cooperative Extension, Blacksburg.

Thompson, J. L. 1972. Swift current forage plot harvester IV. Can. J. Plant Sci. 52:859-860.

Vannoppen, W., M. Vanmaercke, S. De Baets, and J. Poesen. 2015. A review of the mechanical effects of plant roots on concentrated flow erosion rates. Earth Sci. Rev. 150:666-678.

Villamil, M. B., G. A. Bollero, R. G. Darmody, F. W. Simmons, and D. G. Bullock. 2006. No-till corn/soybean systems including winter cover crops. Soil Sci. Soc. Am. J. 70:1936-1944.

Voelker Linton, J. A., and M. S. Allen. 2008. Nutrient demand interacts with forage family to affect intake and digestion responses in dairy cows. J. Dairy Sci. 91:2694-2701.

Wilson, J. R., and P. M. Kennedy. 1996. Plant and animal constraints to voluntary feed intake associated with fibre characteristics and particle breakdown and passage in ruminants. Aust. J. Agric. Res. $47: 199-225$. 